\title{
Psychological methods in treatment of essential hypertension
}

\author{
Pavel Larionov $\mathbb{1 0}$ \\ Faculty of Psychology, Kazimierz Wielki University, Bydgoszcz, Poland
}

\begin{abstract}
Background: The article presents the results of research into the most commonly used methods of psychological support in the treatment of hypertensive patients, including relaxation and meditation techniques, mindfulness training, music therapy, yoga, aromatherapy and biofeedback techniques. Selected psychological aspects of adherence to the antihypertensive treatment are reviewed. Some notes about personality-oriented counselling and psychotherapy in the treatment of hypertension are raised.

Material and methods: In the search for high quality studies, mainly PubMed and EBSCO databases were used, and the journals of such publishers as Elsevier, Hindawi and the American Psychological Association.

Results: Studies on methods of psychological support in hypertensive treatment are mostly controversial due to the lack of assessment of the long-term effects of the intervention, and the complexity of the subject of the study. The most convincing is to use individually selected methods based on the development of mental self-regulation skills (Jacobson's relaxation technique, meditation, biofeedback therapy and mindfulness training). Music therapy, yoga and aromatherapy can also be helpful for patients involved in antihypertensive treatment. Using methods of psychological help, one should take into account restrictions and contraindications, as well as take some precautions. In order to increase the effectiveness of the antihypertensive therapy, it is proposed to conduct health and educational programmes for hypertensive patients, as well as short training courses on communication skills for health care workers.

Conclusion: Responsible use of individually selected assistive treatment psychological methods can be helpful for people with arterial hypertension.
\end{abstract}

Key words: arterial hypertension; methods of psychological support; self-regulation; Jacobson's relaxation technique; music therapy; meditation; biofeedback therapy; yoga; aromatherapy; mindfulness training

Arterial Hypertens. 2021, vol. 25, no. 2, pages: 53-62

DOI: $10.5603 /$ AH.a2021.0002

\section{Introduction}

Essential hypertension (EH) belongs to the group of psychosomatic diseases and is perceived as a multifactorial disorder. It is emphasized that factors of a psychological nature play an important role in the process of development of the disease, and affects the treatment and rehabilitation of patients with $\mathrm{EH}$.
It should be noted that in Polish scientific literature, the importance of the psychological aspect in aetiopathogenesis of $\mathrm{EH}$ is underestimated. In reports devoted to non-pharmacological methods of treatment of EH, as well as the principles of management of $\mathrm{EH}$, the role of stress and coping with difficult situations has been practically ignored $[1,2]$. For example, in the 2019 Guidelines for the Management

Address for correspondence: mgr Pavel Larionov, Kazimierz Wielki University, Staffa Str 1, 85-867 Bydgoszcz, Poland; e-mail: pavel@ukw.edu.pl

This article is available in open access under Creative Common Attribution-Non-Commercial-No Derivatives 4.0 International (CC BY-NC-ND 4.0) license, allowing to download articles and share them with others as long as they credit the authors and the publisher, but without permission to change them in any way or use them commercially 
of Arterial Hypertension by the Polish Society of Hypertension, it was only mentioned that an elevation of blood pressure in young people may be related with a stressful situation, and a specific form of $\mathrm{EH}$, white coat hypertension, was described [3]. However, the importance of stress, especially chronic stress, as well as mental disorders (e.g. anxiety and depression) in the development of $\mathrm{EH}$, and observance of antihypertensive therapy have been specified [4-8]. The key role of dysfunctional emotion regulation in the pathogenesis of $\mathrm{EH}$ was emphasized in leading international cardiological journals [9-11]. In the recommendations by the British institute National Institute for Health and Clinical Excellence (NICE), in the management of $\mathrm{EH}$ in adults in primary health care setting it is recommended to use interventions aimed at the reduction of stress and the promotion of relaxation [12]. In the recommendations by the European Society of Cardiology/European Society of Hypertension (ESC/ESH) concerning management in arterial hypertension published in 2018, it was mentioned that psychosocial factors increase the risk of $\mathrm{EH}$; however, no detailed information was provided about the way it should be considered in prevention, treatment and rehabilitation of patients with EH [13]. Unfortunately, the psychological aspect of EH has not been explained. The development of psychological support and health promotion programmes in $\mathrm{EH}$ in such conditions is difficult.

The most important goal of psychotherapeutic intervention adjusted to the needs of patients with $\mathrm{EH}$, is the shaping and enhancing of the skills for psychical self-regulation, and increasing resistance to the stressful psychological factors. Some methods of psychological support focus on the implementation of changes in the functioning of the emotion regulation processes, and are directly associated with the shaping of psychical self-regulation habits (e.g. techniques based on biofeedback). Other methods of support by indirect mechanisms exert an effect on the psycho-emotional status and cardiovascular system of an individual (e.g. aromatherapy).

The objective of the study is to analyse studies concerning the most frequently used methods of psychological support in the treatment of patients with $\mathrm{EH}$.

\section{Material and methods}

Based on reviews of systematic, randomized and original clinical studies, this study presents conclusions concerning the effectiveness of relaxation and meditation techniques, mindfulness, music therapy, yoga, aromatherapy, techniques based on biofeedback, and personality-oriented psychotherapy in the treatment of EH. Selected psychological aspects are presented of the observance of therapeutic recommendations in patients with $\mathrm{EH}$. In the search for high quality studies, mainly PubMed and EBSCO databases were used, and the journals of such publishers as Elsevier, Hindawi and the American Psychological Association.

\section{Results}

\section{Relaxation}

While fully accepting the principle in medical ethics "First, do no harm", in the most optimum way, simple, safe, and reliable methods for relaxation are used. Among such methods, progressive relaxation acc. to Jacobson is distinguished, which belongs to the dynamic methods of regulation of muscle tension, and is the most universal technique suitable for most people $[14,15]$. A wide review of studies concerning progressive relaxation was presented in Polish in the article by Sławińska [16]. The researcher claims that Jacobson's technique occurred to be effective in the treatment of anxiety, phobia, depression, sleeplessness, EH and other diseases [16]. Many studies have been conducted worldwide concerning the effectiveness of relaxation according to Jacobson in order to treat $\mathrm{EH}$. According to conclusions from these studies and later meta-analyses [17-22], it may be presumed that Jacobson's progressive relaxation technique is an effective non-pharmacological method of supporting patients with EH. The effectiveness of the use of relaxation according to Jacobson in women during pregnancy was also noted [23]. It should be emphasized that in a report by the American Heart Association concerning nonpharmacological methods of treatment of $\mathrm{EH}$, it was stated that a lack of sufficient evidence is observed for the effectiveness of relaxation techniques [24]. This results from the presence of certain methodological difficulties in conducting this type of studies; therefore, evaluation of the effectiveness of relaxation in reducing blood pressure in patients with EH may be equivocal [25].

Jacobson's relaxation technique has its advantages including simple and effective technique suitable for most people, a small number of contraindications, and ease and quickness of learning. In addition, it does not require direct emotion control (in order to reduce psycho-emotional stress it is simply enough to relax muscles); during Jacobson's training no additional equipment is used, unlike for instance in 
music therapy (audio columns) and aromatherapy (aromatic body butters, inhalator); and the training may be performed at any place. Relaxation training leads to the development of the skills of automatic relaxation independent of exercises. Observation and experiencing sensations in muscles during relaxation exercises favours a better understanding of one's own organism which, in turn, contributes to better recognition of tension in their body. This allows an early detection of negative symptoms of stress, and may help to prevent its negative effects.

\section{Music therapy}

Many studies indicated that the use of music therapy exerts an effect on the reduction of blood pressure in patients with EH [26-28]. Music therapy, together with changes of life style, leads to the reduction of blood pressure in people with pre-hypertension [29]. It was confirmed that musical interventions may also be beneficial in order to reduce stress and its negative effects [30]. The Polish researchers, Tadych, Pospiech and Sielski, conducted a study among patients with a history of cerebral stroke and found that music therapy is very important in the prophylaxis of occurrence of secondary cerebral stroke by reducing high blood pressure [31]. The effectiveness of music therapy was also emphasized in the improvement of the quality of life in patients with $\mathrm{EH}$ [32].

Although positive effects of music therapy in persons with EH were observed, Słomiak, Wąsik and Cymerys [33] rightly noted that the available studies show methodological non-uniformity. From the psychotherapeutic point of view, the most important factors affecting the outcomes of music interventions are: quality of music, duration of listening, combination and sequence of various types of melodies, psycho-physiological characteristics of the listener, and a specified psychical status of the person while listening [34]. It is sufficiently difficult to take into account all these factors while conducting scientific studies. It is noteworthy that the use of music therapy in the treatment of patients with $\mathrm{EH}$ should be strictly individualized, in order not to make iatrogenic errors. The valuation of a long-term effect of music interventions requires further studies [33]. It is important to combine music interventions with other methods of support, e.g. relaxation techniques. The effectiveness of such combined interventions has been confirmed [35]. Recognition and expression of one's own feelings and emotions while listening to music may be useful for patients with $\mathrm{EH}$ in order to reduce alexithymic features [34], which are typical of them $[36,37]$. Based on the results of studies it may be presumed that music therapy may be used as an additional effective method of support in the treatment and prevention of $\mathrm{EH}$.

\section{Meditation and mindfulness techniques}

Psychical self-regulation by means of meditation consists in the management of the quality of own thoughts, fantasies, images, etc. The American Heart Association considers that only transcendental meditation may be recommended in clinical practice to patients with EH [24]. Similar results of studies were presented in meta-analyses by Rainfort et al. [38], and Bai et al. [39]. It is worth emphasizing that transcendental meditation shows a greater effectiveness among older people with initially high values of blood pressure [39]. In experimental studies, where adolescents with elevated blood pressure performed mental stress tests, it was found that transcendental meditation exerts a positive effect on the cardiovascular system [40]. However, some researchers indicate a lower effectiveness of transcendental meditation, compared to non-transcendental meditation [41]. Ooi, Giovino and Pak noted that a clear tendency is observed towards increasing evidence which confirms the effectiveness of transcendental meditation in reducing blood pressure [42]. They also found that such a form of meditation while regularly practiced shows a similar effectiveness as diet, physical exercises, and relaxation. Ooi et al. pay attention to the need for conducting studies aimed at the control of long-term effects of transcendental meditation on the reduction of blood pressure [42].

The American Heart Association does not recommend the use in clinical practice of other meditation techniques, consisting in the training of mindfulness, such as Mindfulness-Based Stress Reduction (MBSR) [24]. Nevertheless, Hughes et al. found that MBSR training leads to the reduction of elevated blood pressure in people with pre-hypertension [43]. A Polish researcher, Błaszczak, in a review concerning the effect of MBSR training on physical health, concluded that this training leads to permanent reduction of blood pressure in individuals with EH [44]. Park and Han performed a meta-analysis and confirmed that meditation is especially effective in the treatment of $\mathrm{EH}$ in people aged over 60 [45]. Goldstein et al. noted that transcendental meditation and MBSR may cause a clinically significant reduction of blood pressure in patients with $\mathrm{EH}$, and also indicated the need for further studies [46]. Sangprasert, Palangrit, Tiyoa and Pattaraarchachai showed that mindfulness considerably improves the quality of life, increases the sense of self-efficacy, and exerts a positive effect on the undertaking of behaviours conducive to health among patients with EH [47]. However, Blom et al. 
observed that MBSR does not result in the reduction of blood pressure in people with EH [48]. Ponte et al. observed that at the end of 8-week mindfulness training (2 hours a week), the intervention group of people with EH had statistically significantly lower values of blood pressure (examined using an automatic 24-hour pressure monitoring) than the control group which was not subjected to training. Despite this, 12 weeks after training it was observed that although the mean values of blood pressure were lower in the intervention group, no statistically significant differences were found [49].

Summing-up, it may be presumed that meditation techniques may be useful in the treatment of $\mathrm{EH}$; however, the problem has not been solved concerning long-term stability of the effect of reduction of blood pressure after the trainings. It is noteworthy that while using these techniques, certain contraindications and limitations should be taken into account, and the process of learning is time-consuming and difficult. Meditation requires every day exercises, at best twice daily and for a minimum of 15 minutes. It may be observed that meditation techniques are "intellectualized" too much, and their use by some people may not be easy.

\section{Yoga}

According to the American Heart Association the use of yoga is not currently recommended in clinical practice in order to reduce blood pressure in patients with EH [24]. Nevertheless, this conclusion was drawn due to the lack of reliable, high quality studies concerning the potential effectiveness of blood pressure reduction in patient with EH. Some studies might not have been considered, considering the specific criteria of enrolment of studies into the review. Park and Han found that yoga is helpful in the treatment of $\mathrm{EH}$, although its effect is slightly less, compared to meditation [45]. The researchers stated that yoga is most effective for people aged under 60 [45]. Based on analysis of studies concerning the effectiveness of yoga, Okonta concluded that yoga not only decreases high blood pressure, but also leads to the reduction of blood glucose, cholesterol, and body weight [50]. Important conclusions were drawn by Kobylińska, Lewczuk, Marchlewska and Pietraszek who investigated the relationship between the duration of yoga training and emotion regulation, with consideration of the moderator role of personality traits [51]. This study was conducted among healthy women. People who had practiced yoga for more than one year, compared to those who had trained for a period shorter than a year, more often used the strategy of cognitive reappraisal. It was also noted that the application of yoga may be of little use in people characterized by a high level of neuroticism [51]. It is important and prospective to carry out similar studies among patients with EH. Posadzki et al., based on a systematic review, found that the results of studies concerning the effectiveness of yoga are encouraging, although not entirely convincing [52]. Some researchers very cautiously approach yoga as a method for the treatment of EH, and claim that it is necessary to conduct further high quality studies [53-55]. It should be emphasized that a serious problem occurs with conducting studies of this type. This results from the presence of various traditions of yoga, each proposing a specific approach towards work with the body and brain. For instance, at some schools emphasis is placed on the process of respiration while performing physical exercises, whereas other schools pay more attention to meditation exercises [56]. With respect to yoga, we do not deal with a specific technique containing an established set of exercises, compared to, e.g. Jacobson's relaxation. In such conditions it is complicated to univocally investigate the effectiveness of yoga, which may lead to mixed conclusions.

\section{Aromatherapy}

In the opinion of Zdrojewicz, Minczakowska and Klepacki, aromatherapy shows a calming and antistress effect, which is especially important in the treatment of stress-related diseases, including EH [57]. These researchers state that aromatherapy should be treated as an auxiliary method [57]. Lee, Choi, Posadzki and Ernst carried out a systematic review and found that aromatherapy is not an effective method in the treatment of $\mathrm{EH}$, depression and anxiety [58]. In another review focused on the analysis of the effectiveness of treatment of $\mathrm{EH}$ it was also observed that aromatherapy did not show any effectiveness [59]. It was emphasized that the majority of studies pertaining to the effectiveness of aromatherapy are of low methodological value [58]. Some researchers concluded that aromatherapy has no specific effect on the level of state of anxiety, and its reduction may result from spending time in a quiet, lightened and spacious room during the 10-15 minutes of conducting aromatherapeutic interventions [60].

It was found that after aromatherapeutic inhalations a decrease was observed in the level of serum cortisol and in blood pressure [61, 62]. The use of aromatherapy leads to the reduction of systolic blood pressure and activity of the sympathetic nervous system in patients with $\mathrm{EH}$ [63]. It was emphasized that 10 -minute inhalations with the use of lavender oil 
during 7 days led to the reduction of blood pressure in middle-aged individuals [64]. In other study it was confirmed that lavender oil applied in the form of inhalation leads to a decrease in both state anxiety and trait anxiety, and results in the reduction of blood pressure in patients with myocardial infarction [65]. Massage with the use of essential oils, compared to massage without oils, effectively reduces blood pressure and improves the quality of sleep in women with $\mathrm{EH}[66]$. It was found that a simultaneous use of aromatherapy and music therapy is more effective in reducing blood pressure in pregnant women with $\mathrm{EH}$, than using these interventions separately [67].

Summing-up it may be cautiously concluded about the effectiveness of aromatherapy which should be used as an auxiliary method in people with EH. Nevertheless, for appropriate treatment with the use of aromatherapy, it is necessary to consider the individual characteristics of the users and consultation with a doctor, because there are a number of contraindications and negative effects may occur (e.g. some oils cannot be used by pregnant women).

\section{Techniques based on biofeedback}

In a report by the American Heart Association it was noted that biofeedback may be used in clinical practice in order to reduce blood pressure due to its safety, despite certain equivocal results of studies concerning the effectiveness of this non-pharmaceutical method [24, 68]. There is some evidence of the low quality of such studies and ineffectiveness of procedures based on biofeedback in the treatment of adults with $\mathrm{EH}$, compared to pharmacotherapy, fictitious biofeedback training, lack of interventions, and other behavioural methods [69]. However, in the study by Tsai, Chang, Chang, Lee and Wang, a statistically significant reduction of blood pressure was observed in a group of people with $\mathrm{EH}$ who used biofeedback, compared to patients with $\mathrm{EH}$ who applied fictitious biofeedback (placebo) [70]. The researchers presumed that the specific outcome of treatment using biofeedback might have been caused by a decrease in the body reactivity to stressors [70]. Simultaneously, the use of biofeedback training in combination with relaxation techniques (relaxationassisted biofeedback) caused a considerable reduction of blood pressure in patients with $\mathrm{EH}$ [71]. It is worth emphasizing that studies on the effectiveness of biofeedback therapy in patients with difficult-tocontrol arterial hypertension are worth attention, due to the prevalence of this form of EH [72]. The effectiveness of biofeedback training depends on the personality traits and physiological parameters of the examined person (e.g. reactivity to stress), motiva- tion, observance of recommendations, and shaping the habits of psychical self-regulation [73].

Summing-up, it may be cautiously concluded about the effectiveness of biofeedback training, and it must be taken into account that, similar to other methods, treatment with the use of this training should be individually adjusted, with consideration of a wide spectrum of factors of a bio-psycho-social nature, which exert an effect on the psycho-physiological functioning of an individual.

\section{Psychological aspects of observance of therapeutic recommendations}

Polish patients with EH are characterized by the lowest result with respect to the observance of therapeutic recommendations, compared to inhabitants of Austria, Belgium, England, Germany, Greece, Hungary and Wales ill with EH [74]. The effectiveness of EH treatment in Poland remains on the level of 12\% [75]. According to Krzych, Jaros, Rybicki, Bochenek and Błońska-Fajfrowska, the main causes of ineffectiveness of $\mathrm{EH}$ treatment are: lack of patientdoctor cooperation, lack of patient's the motivation for treatment, non-systematic use of hypotensive drugs, lack of knowledge concerning the disease and goals of therapy, as well as economic aspects [76]. Factors of a patient's psychological nature (primarily patient's cognitive functioning, satisfaction with life, sense of control, and mental state), lack of engagement of a patient in establishing the plan of therapy, as well as the low quality of doctor-patient cooperation, are important aspects in the treatment of EH [77]. The researchers noted that the personality trait 'conscientiousness' in the Big-Five Personality Model (Ten Item Personality Inventory - TIPI was applied), is positively correlated with observance of the rules of management of patients with $\mathrm{EH}$ [78]. Kretchy, Owusu-Daaku and Danquah found that low observance of therapeutic recommendations in patient with $\mathrm{EH}$ was significantly related with a low internal health locus of control, side-effects of drugs and combined effect of side-effects of drugs, and the external health locus of control [79]. A negative relationship was observed between the sense of stress and the observance of medical recommendations and non-healthy life style among people with $\mathrm{EH}$ $[5,80]$. It was noted that the spiritual beliefs of an individual exert a considerable effect on coping with negative emotions associated with $\mathrm{EH}$ [5]. In order to enhance the effectiveness of the therapy of patients with $\mathrm{EH}$, it is proposed to undertake this problem and carry out health programmes aimed at the reduction of stress, and increasing the internal health locus of control $[5,79,80]$. In order to improve the 
effectiveness of $\mathrm{EH}$ treatment, an important aspect is the application of an optimum scheme of dosage of hypotensive drugs and the number of pills taken [81]. According to Matthes and Albus, this is the most effective method which ensures the taking of anti-hypertensive drugs by patients with $\mathrm{EH}$ [82].

A prospective study was conducted in South Africa in which patients with $\mathrm{EH}$, using a mobile phone, received an SMS message reminding them about the most important aspects of treatment and the necessity to report to the clinic. Such a form of assistance occurred to be effective [83]. It may be presumed that the use of automatic systems for sending messages is a promising approach. Studies show that short trainings concerning communication skills for employees of the health sector may considerably improve the effectiveness of treatment of patients with $\mathrm{EH}$ by increasing doctor-patient cooperation. It is proposed to introduce such programmes in educational medical institutions [84].

\section{Discussion}

Conclusions from studies concerning the effectiveness of psychological support for patients with $\mathrm{EH}$ are equivocal and controversial due to serious methodological problems occurring in the procedures for conducting these studies, which do not allow drawing coherent conclusions. As mentioned before, the quality of these studies is low. Confirmation of the effectiveness cannot be justified based on reports where the effectiveness of support for patients with $\mathrm{EH}$ was investigated according to changes in the examined parameters for assessment of effectiveness 'prior and after' intervention without control of long-term parameters. For example, investigation of the state of anxiety and trait anxiety to use meditation, and evaluation of these characteristics after an 8 -week application in conditions of decreased level of anxiety, does not unequivocally evidence the effectiveness of meditation. A patient learning meditation during training sessions remains in the 'caring hands' of a therapist who devotes attention and empathy to the patient, and provides assistance from the aspects of learning and treatment. This may result in positive effects. Control of long-term effects of support methods (e.g. in medical conditions - duration of remission) is most important; however, this control is usually not carried out. It is noteworthy that the vast majority of studies are exclusively based on the model of measurement of effectiveness "prior and after intervention", which does not stand criticism. It is especially important to conduct further stud- ies pertaining to the psychological support methods from the aspect of their effect on the cognitive-emotional functioning of people with EH (e.g. whether there occur changes in the use of adaptive and nonadaptive emotion self-regulation strategies).

While analysing results of the presented study, it may be noted that the methods based on shaping certain habits of psychical self-regulation show the greatest effectiveness. These are techniques based on biofeedback, relaxation, and meditation. The last 2 methods do not require special equipment during learning. Jacobson's relaxation is the most universal method which is also the least demanding with respect to the conditions of use. Meditation techniques are complicated to learn, require long-lasting training, and are not suitable for the majority of people. The use of any methods of support, even the safest Jacobson's relaxation technique, requires strict compliance with security procedures. For example, it is categorically prohibited to carry out relaxation training when the person undergoing training is in a state of psycho-emotional tension, with the presence of unpleasant images, thoughts and sensations in the body. The training should be performed when an individual is in a balanced, psycho-emotional state. It is worth emphasizing that individually-adjusted methods of support are the most effective.

The results of the above-presented studies demonstrate that a simultaneous use of two or more methods leads to more effective reduction of blood pressure in patients with $\mathrm{EH}$. While using music therapy, it may be proposed to apply additional psychotherapeutic techniques exerting an effect on the emotional functioning of an individual. This would allow a patient with $\mathrm{EH}$ to more deeply recognize own intrapsychic processes and learn to regulate own emotional states [34]. Such a use would enable the shaping of habits of psychical self-regulation. In fact, a sole listening to the music looks less promising. The use of music therapy requires an exclusively individual approach to a particular patient.

Considering the variety of yoga schools and their techniques it is relatively difficult to determine the effectiveness of yoga. Being a philosophical tradition from the East, in the West, yoga is understood more as a "set of exercises for the body". Such an understanding concerns more hatha yoga, and not, for example, Raja yoga, the aim of which is learning the management of thinking. The majority of the presented studies deal with hatha yoga. Considering the fact that this form of yoga requires the performance of physical exercises, and physical activity is recommended for people with $\mathrm{EH}$ [3], it may be assumed that individually adjusted exercises which 
result in a positive result may be applied in patients with $\mathrm{EH}$.

Aromatherapy is a useful method of support for patients with $\mathrm{EH}$ after consideration of several aspects. Firstly, an individual selection of an essential oil should be considered which exerts a positive effect on the cardiovascular system and general well-being of the patient. Secondly, aromatherapy may be used in combination with other techniques, e.g. relaxation or meditation. Thirdly, in order to facilitate the use of aromatherapy in daily life, pendants or bracelets specially designed for this are applied which are diffusers of essential oils. The isolated use of aromatherapy is rather a symptomatic approach in the treatment of $\mathrm{EH}$ which, however, may be satisfactory for some time. It is known that essential oils cause changes in the human psycho-emotional state. Patients may assess these changes and recognize own feelings and emotions occurring during the process of aromatherapy. This contributes to the development of the sense of smell. It should be noted that a low capability for sensing smell or taste experiences is also characteristic of alexithymia [85] which, as emphasized above, is a specific feature of patients with EH. It may be presumed that the use of such a modified form of aromatherapy allows learning of own psycho-emotional state, and thus its regulation in the future.

Currently, within support for patients with $\mathrm{EH}$, no studies have been presented concerning long-term forms of psychotherapy (e.g. existential), or shortlasting forms oriented towards a patient's personality, and the system of a patient's relations with the surrounding reality (e.g. specificity of patient's emotional functioning in situations which cause emotional tension, etc.). Studies concerning the effectiveness of such individualized psychotherapy, adjusted to a given patient, are very complicated to conduct. However, the lack of this type of studies does not exclude the effectiveness of such forms of psychotherapy for patients with $\mathrm{EH}$.

\section{Conclusion}

Studies concerning the effectiveness of the methods of psychological support for patients with $\mathrm{EH}$ are controversial due to their low quality and the presence of methodological problems, which cannot be solved within evidence-based medicine. The most effective methods are those which, firstly, are individually selected for a given patient, and secondly, are directly related with shaping mental selfregulation skills (relaxation, meditation, techniques based on biofeedback). Primarily, it is important to pay attention to the most universal and safe methods which do not require additional equipment for training (Jacobson's relaxation). For a time, non-specific methods of support for patients with EH may be useful, which do not exert a direct effect on shaping conscious skills of psychical self-regulation (yoga, aromatherapy, music therapy). Nevertheless, the use of these methods may be very useful for patients engaged in the application of techniques individually selected for them. Modification from the aspect of their use via inclusion of psychological elements based on the methods proposed in this article creates new possibilities for using psychological support methods. Special attention should be paid to safety while applying the above-mentioned methods because, despite seeming safe, there are contraindications for their use.

Considering the above-described aspects, it may be concluded that the use of the methods of psychological support in patients with $\mathrm{EH}$ is the approach which possesses both medical and scientific potential.

\section{References}

1. Grodzicki T, Gryglewska B, Tomasik T, et al. Zasady postępowania w nadciśnieniu tętniczym w wieku podeszłym. Med Wieku Podeszłego. 2013; 3(1): 1-27.

2. Kobus G, Łagoda K, Bachórzewska-Gajewska H. Niefarmakologiczne metody leczenia dzieci i młodych osób chorych na nadciśnienie tętnicze. Endokrynol Otył Zab Przem Mat. 2008; 4(4): 163-167.

3. Tykarski A, Filipiak KJ, Januszewicz A, et al. Zasady postępowania w nadciśnieniu tętniczym - 2019 rok. Wytyczne Polskiego Towarzystwa Nadciśnienia Tętniczego. Nadciśnienie Tętnicze w Praktyce. 2019; 5(1): 1-86.

4. Jodłowska E, Juszczak M. Wpływ stresu przewlekłego na rozwój nadciśnienia tętniczego. Folia Medica Lodziensia. 2013; 40(1): 53-77.

5. Kretchy IA, Owusu-Daaku FT, Danquah SA. Mental health in hypertension: assessing symptoms of anxiety, depression and stress on anti-hypertensive medication adherence. Int J Ment Health Syst. 2014; 8: 25, doi: $10.1186 / 1752-4458-8-25$, indexed in Pubmed: 24987456.

6. Moryś J, Jeżewska M, Rynkiewicz A. Znaczenie stresu w patogenezie nadciśnienia tętniczego. Część I. Nadciśn Tętn. 2005; 9(1): 1-10.

7. Spruill TM. Chronic psychosocial stress and hypertension. Curr Hypertens Rep. 2010; 12(1): 10-16, doi: 10.1007/s11906-0090084-8, indexed in Pubmed: 20425153.

8. Stein DJ, Aguilar-Gaxiola S, Alonso J, et al. Associations between mental disorders and subsequent onset of hypertension. Gen Hosp Psychiatry. 2014; 36(2): 142-149, doi: 10.1016/j.genhosppsych.2013.11.002, indexed in Pubmed: 24342112.

9. Consoli SM, Lemogne C, Roch B, et al. Differences in emotion processing in patients with essential and secondary hypertension. Am J Hypertens. 2010; 23(5): 515-521, doi: 10.1038/ ajh.2010.9, indexed in Pubmed: 20134404.

10. Symonides B, Holas P, Schram M, et al. Does the control of negative emotions influence blood pressure control and its variability? Blood Press. 2014; 23(6): 323-329, doi: 10.3109/08037051.20 14.901006, indexed in Pubmed: 24786662.

11. Trudel-Fitzgerald C, Gilsanz P, Mittleman MA, et al. Dysregulated Blood Pressure: Can Regulating Emotions Help? Curr Hyper- 
tens Rep. 2015; 17(12): 92, doi: 10.1007/s11906-015-0605-6, indexed in Pubmed: 26520446.

12. Redakcja Nadciśnienia Tętniczego. Wytyczne NICE. Postępowanie w nadciśnieniu tętniczym u dorosłych w podstawowej opiece zdrowotnej. Nadciśn Tętn. 2006; 10(4): 307-324.

13. Williams B, Mancia G, Spiering W, et al. 2018 ESC/ESH Guidelines for the management of arterial hypertension. Kardiol Pol. 2019: 71-159, doi: 10.5603/kp.2019.0018.

14. Everly GS, Rosenfeld R. The Nature and Treatment of the Stress Response: A Practical Guide for Clinicians. Plenum Press, London, New York 1981.

15. Jacobson E. You Must Relax: A Practical Method of Reducing the Strains of Modern Living. American J Psychol. 1943; 56(3): 474, doi: $10.2307 / 1417412$.

16. Sławińska A. Zastosowanie progresywnej relaksacji mięśni Jacobsona w praktyce klinicznej. Psychiatria i Psychoterapia. 2016; 12(4): 3-15

17. Chauhan R, Sharma A. Effectiveness of Jacobson's Progressive Muscle Relaxation Therapy to Reduce Blood Pressure among Hypertensive Patient-a Literature Review. Int J Nurs Care. 2017; 5(1): 26, doi: 10.5958/2320-8651.2017.00006.0.

18. Khatri SM, Singaravelan RM, Romi HN. Effectiveness of Jacobson's Relaxation Technique in Hypertension. Int J Health Sci Res. 2012; 1(2): 16-21.

19. Prabu I. A Study to Assess the Effectiveness of Jacobson's Progressive Muscle Relaxation Exercise on Blood Pressure among Patients with Hypertension in Christian Mission Hospital at Madurai. Asian J Nurs Edu Res. 2017; 7(4): 529, doi: 10.5958/23492996.2017.00104.5.

20. Rosdiana I, Cahyati Y. Effect of Progressive Muscle Relaxation (PMR) on Blood Pressure among Patients with Hypertension. Int J Adv Life Sci Res. 2019; 2(1): 28-35, doi: 10.31632/ ijalsr.2019v02i01.005.

21. Sheu S, Irvin BL, Lin HS, et al. Effects of progressive muscle relaxation on blood pressure and psychosocial status for clients with essential hypertension in Taiwan. Holist Nurs Pract. 2003; 17(1): 41-47, doi: 10.1097/00004650-200301000-00009, indexed in Pubmed: 12597674.

22. Shinde N, Shinde KJ, Khatri SM, et al. Immediate Effect of Jacobson's Progressive Muscular Relaxation in Hypertension. Indian J Physiother Occupation Ther Int J. 2013; 7(3): 234, doi: 10.5958/j.0973-5674.7.3.098.

23. Aalami M, Jafarnejad F, ModarresGharavi M. The effects of progressive muscular relaxation and breathing control technique on blood pressure during pregnancy. Iran J Nurs Midwifery Res. 2016; 21(3): 331-336, doi: 10.4103/1735-9066.180382, indexed in Pubmed: 27186213.

24. Brook RD, Appel LJ, Rubenfire M, et al. American Heart Association Professional Education Committee of the Council for High Blood Pressure Research, Council on Cardiovascular and Stroke Nursing, Council on Epidemiology and Prevention, and Council on Nutrition, Physical Activity. Beyond medications and diet: alternative approaches to lowering blood pressure: a scientific statement from the american heart association. Hypertension. 2013; 61(6): 1360-1383, doi: 10.1161/HYP.0b013e318293645f, indexed in Pubmed: 23608661.

25. Dickinson Ho, Campbell F, Beyer Fr, et al. Relaxation therapies for the management of primary hypertension in adults: a Cochrane review. J Hum Hypertens. 2008; 22(12): 809-820, doi: 10.1038/jhh.2008.65, indexed in Pubmed: 18548088.

26. do Amaral MA, Neto MG, de Queiroz JG, et al. Effect of music therapy on blood pressure of individuals with hypertension: A systematic review and Meta-analysis. Int J Cardiol. 2016; 214: 461-464, doi: 10.1016/j.ijcard.2016.03.197, indexed in Pubmed: 27096963.

27. Im-Oun S, Kotruchin P, Thinsug P, et al. Effect of Thai instrumental folk music on blood pressure: A randomized controlled trial in stage- 2 hypertensive patients. Complement Ther Med. 2018; 39: 43-48, doi: 10.1016/j.ctim.2018.05.014, indexed in Pubmed: 30012391.
28. Kühlmann AYR, Etnel JRG, Roos-Hesselink JW, et al. Systematic review and meta-analysis of music interventions in hypertension treatment: a quest for answers. BMC Cardiovasc Disord. 2016; 16: 69, doi: 10.1186/s12872-016-0244-0, indexed in Pubmed: 27095510.

29. Kunikullaya KU, Goturu J, Muradi V, et al. Combination of music with lifestyle modification versus lifestyle modification alone on blood pressure reduction - A randomized controlled trial. Complement Ther Clin Pract. 2016; 23: 102-109, doi: 10.1016/j. ctcp.2015.05.004, indexed in Pubmed: 26007202.

30. de Witte M, Spruit A, van Hooren S, et al. Effects of music interventions on stress-related outcomes: a systematic review and two meta-analyses. Health Psychol Rev. 2020; 14(2): 294-324, doi: 10 $.1080 / 17437199.2019 .1627897$, indexed in Pubmed: 31167611.

31. Tadych A, Pospiech W, Sielski Ł. Wpływ muzykoterapii receptywnej na ciśnienie tętnicze krwi podczas zabiegów masażu leczniczego u pacjentów po przebytym udarze mózgu. J Edu Health Sport. 2016; 6(10): 263-278, doi: 10.5281/zenodo.162076.

32. Zanini CR, Jardim PC, Salgado CM, et al. Music therapy effects on the quality of life and the blood pressure of hypertensive patients. Arq Bras Cardiol. 2009; 93(5): 534-540, doi: 10.1590/ s0066-782x2009001100015, indexed in Pubmed: 20084316.

33. Słomiak A, Wąsik N, Cymerys M. Wpływ muzyki na częstość rytmu serca oraz ciśnienie tętnicze — przegląd literatury. Forum Zaburzeń Metabolicznych. 2018; 9(3): 119-125.

34. Paszkiewicz-Mes E. Muzykoterapia jako metoda wspomagająca leczenie. Hygeia Public Health. 2013; 48(2): 168-176.

35. Astuti NF, Rekawati E, Wati DN. Decreased blood pressure among community dwelling older adults following progressive muscle relaxation and music therapy (RESIK). BMC Nurs. 2019; 18(Suppl 1): 36, doi: 10.1186/s12912-019-0357-8, indexed in Pubmed: 31427898.

36. Chachaj A, Małyszczak K, Kucharski W, et al. Personality characteristics of patients with essential hypertension. Med Sci Tech. 2009; 50(2): 93-97.

37. Piotrowska-Półrolnik M, Holas P, Krejtz I, et al. Relationship between alexithymia and variability of blood pressure measured with ABPM in hypertensive patients. Gen Hosp Psychiatry. 2019; 60: 1-5, doi: 10.1016/j.genhosppsych.2019.04.014, indexed in Pubmed: 31229676.

38. Rainforth MV, Schneider RH, Nidich SI, et al. Stress reduction programs in patients with elevated blood pressure: a systematic review and meta-analysis. Curr Hypertens Rep. 2007; 9(6): 520-528, doi: 10.1007/s11906-007-0094-3, indexed in Pubmed: 18350109.

39. Bai Z, Chang J, Chen C, et al. Investigating the effect of transcendental meditation on blood pressure: a systematic review and meta-analysis. J Hum Hypertens. 2015; 29(11): 653-662, doi: 10.1038/jhh.2015.6, indexed in Pubmed: 25673114.

40. Barnes VA, Treiber FA, Davis H. Impact of Transcendental Meditation on cardiovascular function at rest and during acute stress in adolescents with high normal blood pressure. J Psychosom Res. 2001; 51(4): 597-605, doi: 10.1016/s0022-3999(01)00261-6, indexed in Pubmed: 11595248.

41. Shi Lu, Zhang D, Wang L, et al. Meditation and blood pressure: a meta-analysis of randomized clinical trials. J Hypertens. 2017; 35(4): 696-706, doi: 10.1097/HJH.0000000000001217, indexed in Pubmed: 28033127.

42. Ooi SL, Giovino M, Pak SC. Transcendental meditation for lowering blood pressure: An overview of systematic reviews and meta-analyses. Complement Ther Med. 2017; 34: 26-34, doi: 10.1016/j.ctim.2017.07.008, indexed in Pubmed: 28917372.

43. Hughes JW, Fresco DM, Myerscough R, et al. Randomized controlled trial of mindfulness-based stress reduction for prehypertension. Psychosom Med. 2013; 75(8): 721-728, doi: 10.1097/ PSY.0b013e3182a3e4e5, indexed in Pubmed: 24127622.

44. Błaszczak A. The Influence of Mindfulness Stress Based Reduction Training on Somatic Health. Ann UMCS Sect J. 2018; 31(1): 61-73, doi: 10.17951/j.2018.31.1.61-73. 
45. Park SH, Han KS. Blood Pressure Response to Meditation and Yoga: A Systematic Review and Meta-Analysis. J Altern Complement Med. 2017; 23(9): 685-695, doi: 10.1089/acm.2016.0234, indexed in Pubmed: 28384004.

46. Goldstein CM, Josephson R, Xie S, et al. Current perspectives on the use of meditation to reduce blood pressure. Int J Hypertens. 2012; 2012: 578397, doi: $10.1155 / 2012 / 578397$, indexed in Pubmed: 22518287.

47. Sangprasert P, Palangrit S, Tiyoa N, et al. Effects of mindfulnessbased health education practice on health behaviors and quality of life among hypertensive patients. J Health Res. 2019; 33(3): 186-196, doi: 10.1108/jhr-07-2018-0059.

48. Blom K, Baker B, How M, et al. Hypertension analysis of stress reduction using mindfulness meditation and yoga: results from the HARMONY randomized controlled trial. Am J Hypertens. 2014; 27(1): 122-129, doi: 10.1093/ajh/hpt134, indexed in Pubmed: 24038797.

49. Ponte Márquez PH, Feliu-Soler A, Solé-Villa MJ, et al. Benefits of mindfulness meditation in reducing blood pressure and stress in patients with arterial hypertension. J Hum Hypertens. 2019; 33(3): 237-247, doi: 10.1038/s41371-018-0130-6, indexed in Pubmed: 30425326

50. Okonta NR. Does yoga therapy reduce blood pressure in patients with hypertension?: an integrative review. Holist Nurs Pract. 2012; 26(3): 137-141, doi: 10.1097/HNP.0b013e31824ef647, indexed in Pubmed: 22517349.

51. Kobylińska D, Lewczuk K, Marchlewska M, et al. For Body and Mind: Practicing Yoga and Emotion Regulation. Soc Psychol Bull. 2018; 13(1): e25502, doi: 10.5964/spb.v13i1.25502.

52. Posadzki P, Cramer H, Kuzdzal A, et al. Yoga for hypertension: a systematic review of randomized clinical trials. Complement Ther Med. 2014; 22(3): 511-522, doi: 10.1016/j.ctim.2014.03.009, indexed in Pubmed: 24906591.

53. Cramer H, Haller H, Lauche R, et al. A systematic review and meta-analysis of yoga for hypertension. Am J Hypertens. 2014; 27(9): 1146-1151, doi: 10.1093/ajh/hpu078, indexed in Pubmed: 24795403.

54. Hagins M, States R, Selfe T, et al. Effectiveness of yoga for hypertension: systematic review and meta-analysis. Evid Based Complement Alternat Med. 2013; 2013: 649836, doi: 10.1155/2013/649836, indexed in Pubmed: 23781266.

55. Wang J, Xiong X, Liu W. Yoga for essential hypertension: a systematic review. PLoS One. 2013; 8(10): e76357, doi: 10.1371/ journal.pone.0076357, indexed in Pubmed: 24124549.

56. Eliade M. Techniki jogi. Wydawnictwo Aletheia, Warszawa 2009.

57. Zdrojewicz Z, Minczakowska K, Klepacki K. Rola aromaterapii w medycynie. Fam Med Primary Care Rev. 2014; 16(4): 387-391.

58. Lee MS, Choi J, Posadzki P, et al. Aromatherapy for health care: an overview of systematic reviews. Maturitas. 2012; 71(3): 257-260, doi: 10.1016/j.maturitas.2011.12.018, indexed in Pubmed: 22285469.

59. Hur MH, Lee MS, Kim C, et al. Aromatherapy for treatment of hypertension: a systematic review. J Eval Clin Pract. 2012; 18(1): 37-41, doi: 10.1111/j.1365-2753.2010.01521.x, indexed in Pubmed: 20695948.

60. Eren NB, Oztunc G. The Effects of Aromatherapy on the Stress and Anxiety Levels of Nurses Working in Intensive Care Units. Int J Caring Sci. 2017; 10(3): 1615-1622.

61. Lee Mk, Lim S, Song JA, et al. The effects of aromatherapy essential oil inhalation on stress, sleep quality and immunity in healthy adults: Randomized controlled trial. Eur J Integrat Med. 2017; 12: 79-86, doi: 10.1016/j.eujim.2017.04.009.

62. Kim IH, Kim C, Seong K, et al. Essential oil inhalation on blood pressure and salivary cortisol levels in prehypertensive and hypertensive subjects. Evid Based Complement Alternat Med. 2012; 2012: 984203, doi: 10.1155/2012/984203, indexed in Pubmed: 23259002.

63. Cha JH, Lee SH, Yoo YS. [Effects of aromatherapy on changes in the autonomic nervous system, aortic pulse wave velocity and aortic augmentation index in patients with essential hyperten- sion]. J Korean Acad Nurs. 2010; 40(5): 705-713, doi: 10.4040/ jkan.2010.40.5.705, indexed in Pubmed: 21157172.

64. Suidah H, Murtiyani N, Fibriana L, et al. The Effectiveness of Lavender Aromatherapy In Changing Blood Pressure In Middle Age With Primary Hypertension In Mojokerto Regency Of East Java Province. Adv Soc Sci Res J. 2018; 5(2), doi: 10.14738/ assrj. 52.4114

65. Mirbastegan N, Ganjloo J, Bakhshandeh Bavarsad M. Effects of Aromatherapy on Anxiety and Vital Signs of Myocardial Infarction Patients in Intensive Care Unit. Int Med J Mal. 2016; 2(15): 37-42.

66. Ju MS, Lee S, Bae I, et al. Effects of aroma massage on home blood pressure, ambulatory blood pressure, and sleep quality in middle-aged women with hypertension. Evid Based Complement Alternat Med. 2013; 2013: 403251, doi: 10.1155/2013/403251, indexed in Pubmed: 23431338.

67. Maisi S, Suryono S, Widyawati M, et al. Effectiveness of lavender aromatherapy and classical music therapy in lowering blood pressure in pregnant women with hypertension. Belitung Nursing Journal. 2017; 3(6): 750-756, doi: 10.33546/bnj.301.

68. Oza R, Garcellano M. Nonpharmacologic management of hypertension: what works? Am Fam Physician. 2015; 91(11): 772-776, indexed in Pubmed: 26034854

69. Greenhalgh J, Dickson R, Dundar Y. The effects of biofeedback for the treatment of essential hypertension: a systematic review. Health Technol Assess. 2009; 13(46): 1-104, doi: 10.3310/ hta13460, indexed in Pubmed: 19822104.

70. Tsai PS, Chang NC, Chang WY, et al. Blood pressure biofeedback exerts intermediate-term effects on blood pressure and pressure reactivity in individuals with mild hypertension: a randomized controlled study. J Altern Complement Med. 2007; 13(5): 547-554, doi: $10.1089 / \mathrm{acm} .2007 .6289$, indexed in Pubmed: 17604559 .

71. Nakao M, Yano E, Nomura S, et al. Blood pressure-lowering effects of biofeedback treatment in hypertension: a meta-analysis of randomized controlled trials. Hypertens Res. 2003; 26(1): 37-46, doi: 10.1291/hypres.26.37, indexed in Pubmed: 12661911.

72. Tymoshenko OS. The effectiveness of biofeedback in the treatment of difficult-to-control arterial hypertension. Journal of $\mathrm{V}$. N. Karazin KhNU. Series Medicine. 2016; 32: 93-111.

73. McGrady A. The effects of biofeedback in diabetes and essential hypertension. Cleve Clin J Med. 2010; 77 Suppl 3: S68-S71, doi: 10.3949/ccjm.77.s3.12, indexed in Pubmed: 20622080.

74. Morrison VL, Holmes EAF, Parveen S, et al. Predictors of self-reported adherence to antihypertensive medicines: a multinational, cross-sectional survey. Value Health. 2015; 18(2): 206-216, doi: 10.1016/j.jval.2014.12.013, indexed in Pubmed: 25773556.

75. Rycombel A, Lomper K, Uchmanowicz I. Adherence i compliance w leczeniu nadciśnienia tętniczego. Nadciśn Tętn. 2014; 18(3): 151-158.

76. Krzych ŁK, Jaros A, Rybicki J, et al. Skuteczność leczenia nadciśnienia tętniczego u chorych hospitalizowanych na oddziale rehabilitacji kardiologicznej. Nadciśn Tętn. 2010; 14(4): 261-266.

77. Winnicki M, Basiński K, Szyndler A, et al. Jak poprawić stopień przestrzegania zaleceń terapeutycznych i jakość współpracy lekarz-pacjent? Choroby Serca i Naczyń. 2016; 13(3): 194-202.

78. Kretchy IA, Acheampong F, Laryea J, et al. Personality Traits, Clinical Characteristics, and Health-Related Quality of Life of Patients with Hypertension in a Primary Hospital in Ghana. Int J Hypertens. 2019; 2019: 7489875, doi: 10.1155/2019/7489875, indexed in Pubmed: 30719339.

79. Kretchy I, Owusu-Daaku F, Danquah S. Locus of control and anti-hypertensive medication adherence in Ghana. Pan Afr Med J. 2014; 17, doi: 10.11604/pamjs.supp.2014.17.1.3433.

80. Doubova SV, Martinez-Vega IP, Aguirre-Hernandez R, et al. Association of hypertension-related distress with lack of selfcare among hypertensive patients. Psychol Health Med. 2017; 22(1): 51-64, doi: 10.1080/13548506.2016.1239830, indexed in Pubmed: 27677320.

81. Szczęch R, Szyndler A, Kolasińska-Malkowska K, et al. Możliwości poprawy skuteczności leczenia nadciśnienia tętniczego 
poprzez zwiększenie przestrzegania zaleceń przez pacjentów — korzyści stosowania leków łączonych. Nadciśn Tętn. 2007; 11(6): 525-535.

82. Matthes J, Albus C. Improving adherence with medication: a selective literature review based on the example of hypertension treatment. Dtsch Arztebl Int. 2014; 111(4): 41-47, doi: 10.3238/ arztebl.2014.0041, indexed in Pubmed: 24612495.

83. Leon N, Surender R, Bobrow K, et al. Improving treatment adherence for blood pressure lowering via mobile phone SMS-messages in South Africa: a qualitative evaluation of the
SMS-text Adherence SuppoRt (StAR) trial. BMC Fam Pract. 2015; 16: 80, doi: 10.1186/s12875-015-0289-7, indexed in Pubmed: 26137844.

84. Sany ST, Peyman N, Behzhad F, et al. Health providers' communication skills training affects hypertension outcomes. Medical Teacher. 2017; 40(2): 154-163, doi: 10.1080/0142159x.2017. 1395002.

85. Cecchetto C, Rumiati RI, Aiello M. Alexithymia and emotional reactions to odors. Sci Rep. 2017; 7(1): 14097, doi: 10.1038/ s41598-017-14404-x, indexed in Pubmed: 29074970. 